\title{
Field Performance of Transgenic Potato, with Resistance to Colorado Potato Beetle and Viruses
}

\author{
David R. Duncan, David Hammond, Jim Zalewski, John Cudnohufsky, Wojciech Kaniewski, \\ Mike Thornton, Jeffrey T. Bookout, Paul Lavrik, Glennon J. Rogan, and Jennifer Feldman-Riebe \\ Monsanto Co., mail zone GG4C, 700 Chesterfield Parkway North, St. Louis, MO 63198
}

Additional index words. Bacilllus thuringiensis, potato leaf roll virus, potato virus $\mathrm{Y}$

In the United States, potato (Solanum tuberosum L.) is second only to wheat (Triticum aestivum L.) in importance as a crop used primarily for human consumption (as opposed to those crops used primarily for livestock feed or vegetable oil). Potato is the largest vegetable crop, representing $15 \%$ of all vegetable cash receipts in 1997. In 1997, the farm value of the potato crop was valued between $\$ 2$ and $\$ 3$ billion dollars with 526,000 ha planted and 20.9 billion $\mathrm{kg}$ of potato harvested (Evans, 1997). These potatoes were consumed as either fresh-market potatoes or as potatoes processed into chips, fries, frozen products, or dehydrated products (Table 1).

Potato is a vegetatively propagated crop which is plagued by numerous disease organisms and pests: Colorado potato beetle (Leptinotarsa decemlineata Say), potato virus Y, and potato leaf roll virus to name a few. These particular pests and pathogens are some of the most devastating in North America, with large expense and effort devoted each year to minimizing their effects on potato production (Banttari et al., 1993; Ferro and Boiteau, 1993). Monsanto has developed, through Agrobacterium tumefaciens-mediated transformation, several genetically modified potato cultivars that provide "built-in" protection from these organisms while maintaining superior agronomic performance. Some of these products have been commercially available since 1995, and in 1998 were planted on 20,000 ha in North America (Table 2).

In this paper, we will examine these Monsanto products and present results concerning the stability of their inserted genes.

\section{MONSANTO PRODUCT DEVELOPMENT}

NewLeaf®. NewLeaf potatoes were created by the insertion of a gene for a bacterial protein endotoxin (Bt) from Bacillus thuringiensis var. tenebrionis (Perlak et al., 1993) into 'Russet Burbank', 'Atlantic', 'Snowden', and 'Superior' potato cultivars. The Bt protein confers unmatched, season-long control of Colorado potato beetle without the application of chemical insecticides. Both the larvae and adults Colorado potato beetle feed on the foliage of potato plants. They can reduce yields as much as $85 \%$ and season-long chemical control can cost from $\$ 12.00$ to $\$ 49.00$ per ha (James, 1998). Although insecticides are used on other problem insects in potato fields, in 1996 and 1997 the use of NewLeaf potato reduced insecticide use on average $40 \%$, or 1.2 sprays per growing season (James, 1998). Thus NewLeaf potato presents the potato grower with an opportunity to realize greater economic returns with reduced environmental impact.

To maintain the utility of this product for the grower, the susceptibility of Colorado potato beetle to the protein and the expression of the $\operatorname{cry} 3 \mathrm{~A}$ gene within the potato plant must be consistent from one growing season to the next. To reduce the likelihood of resistance developing against the protein, Monsanto is recommending to growers of the product that they 1) plant $20 \%$ of their field area in non-Btcontaining potato as a refuge for susceptible Colorado potato beetle, 2) reduce the overall population of Colorado potato beetle by rotating crops and rotating the fields on which NewLeaf potatoes are planted, and 3) monitor their NewLeaf crop for the presence of surviving Colorado potato beetles. Thus far, from field monitoring, no case of resistant Colorado potato beetle has been reported.

To determine the consistency of cry $3 A$ gene expression over multiple generations, a field experiment was conducted in 1998 in which three potato field generations (FG) were planted at one time and assayed simultaneously by quantitative enzyme linked immunosorbent

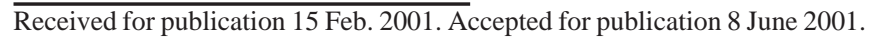

assay (ELISA) for the Bt protein. A FG is represented by the potatoes harvested from a potato field. These potatoes can be used, whole or in pieces, as vegetative propagules for the next year's potato field. The FG is sequentially numbered beginning with the first potatoes generated (FG1) from tissue culture derived plants. By beginning new field plots from tissue culture plants in three consecutive years, a sequence of three different FG were generated and they could all be planted in the same season for the expression analysis. This type of experimental design avoided the complication of comparing ELISA results from different years. Results from this work indicated that there was no difference in the Bt protein expression level over three field generations (Table 3). Although the results compare different ELISA assays, there was also no significant difference seen between results obtained in this experiment and those obtained 4 years earlier (Table 3 ).

NewLeaf Plus®. NewLeaf Plus potatoes were created by the insertion of a gene for the replicase protein of the potato leaf roll virus (PLRV) and the gene for a bacterial protein endotoxin (Bt) from Bacillus thuringiensis var. tenebrionis. PLRV is an aphid transmitted virus that can also be transmitted from one growing season to another by the planting of infected potatoes. In the second growing season after infection, yield loss can be as high as $50 \%$ to $80 \%$ (Banttari et al., 1993). More significant, however, is an internal tuber defect called net necrosis that results in some varieties (e.g., 'Russet Burbank') from PLRV infection. Net necrosis can be a major quality defect causing substantial economic loss for potato growers. Typical control of PLRV is through controlling the aphid vector population, planting seed potato in areas with reduced aphid presence, and through the certification of seed potato as virus free (Slack, 1993). NewLeaf Plus, which has been commercially available only since the spring of 1999 , provides season-long control against disease development of PLRV in

Table 1. Per capita consumption in the United States of potato in $1996^{z}$ (Evans, 1997).

\begin{tabular}{lc}
\hline \hline Form in which potato & $\begin{array}{c}\text { Product consumption } \\
\text { on a fresh wt basis }(\mathrm{kg})\end{array}$ \\
\hline Frozen products & 26.7 \\
Fresh & 21.8 \\
Dehydrated products & 8.2 \\
Chips \& Shoe string fries & 7.2 \\
Total & 63.9 \\
\hline
\end{tabular}

From Evans (1997).

Table 2. NewLeaf® Commercial adoption rate of cultivars: 'Russet Burbank', 'Atlantic', 'Snowden', and 'Superior'.

\begin{tabular}{lcc}
\hline $\begin{array}{l}\text { Production } \\
\text { year }\end{array}$ & $\begin{array}{c}\text { Area } \\
\text { commercial } \\
\text { production (ha) }\end{array}$ & $\begin{array}{c}\text { Raw product for } \\
\text { table stock \& fries } \\
\text { (Million kg) }\end{array}$ \\
\hline 1995 & 729 & 25 \\
1996 & 4,374 & 136 \\
1997 & 16,524 & 409 \\
1998 & 19,440 & 636 \\
\hline
\end{tabular}

Table 3. Bt protein expression level over several field generations (FG) in two transgenic potato cultivars.

\begin{tabular}{lcccc}
\hline & \multicolumn{4}{c}{ Bt protein $\left(\mu \mathrm{g} \cdot \mathrm{g}^{-1}\right.$ fresh wt) } \\
\cline { 2 - 5 } & 1994 & \multicolumn{3}{c}{1998} \\
\cline { 2 - 5 } Cultivar & FG1 & FG1 & FG2 & FG3 \\
\hline $\begin{array}{l}\text { Newleaf® } \\
\text { Atlantic }\end{array}$ & $13.00 \pm 0.00$ & $12.81 \pm 0.53$ & $13.26 \pm 1.86$ & $14.61 \pm 5.42$ \\
Newleaf ${ }^{\circledR}$ & & & & \\
Russet Burbank & $5.00 \pm 0.00$ & $5.71 \pm 0.36$ & $6.12 \pm 1.38$ & $7.53 \pm 2.06$ \\
\hline
\end{tabular}


addition to control of Colorado potato beetle. This disease control strategy, as indicated by lack of disease symptoms and no development of net necrosis in NewLeaf Plus plants and tubers, has been effective against artificial inoculation of plants with 64 different PLRV isolates over a 3-year period.

The replicase m-RNA, but not the protein, has been detected in the NewLeaf Plus plants. Since no detectable protein is produced, another means of determining the stability of the gene's expression has been to examine potato "seed" certification records. Certified potato seed are potato tubers that were developed under the inspection of a state certification agency and verified, through laboratory analysis, to contain less virus than a specified threshold level (Slack, 1993). Records for 1995 and 1996 show that no PLRV was detected in laboratory analysis of 141 NewLeaf Plus fields sampled (Table 4). Whereas $35 \%$ of the non-NewLeaf Plus fields sampled contained unacceptable levels of PLRV (Table 4). Mosaic symptoms were found in both NewLeaf Plus and non-NewLeaf Plus potatoes since neither had protection from PVY or any other mosaic-causing virus.

NewLeaf $Y ®$. NewLeaf Y potatoes were created by the insertion of a gene for the coat protein from potato virus Y (PVY) and the gene for a bacterial protein endotoxin (Bt) from Bacillus thuringiensis var. tenebrionis. Like PLRV, PVY is an aphid transmitted virus which can also be transmitted from one growing season to another by the planting of infected potatoes. PVY causes a mosaic symptom and leaf drop, with yield losses ranging from 10\% to $80 \%$ (Banttari et al., 1993).

NewLeaf Y, which has been commercially available only since the spring of 1999, provides season-long control against disease development of PVY in addition to control of Colorado potato beetle. Disease control, as indicated by lack of disease symptoms in NewLeaf Y plants, has been effective against artificial inoculation of plants over a 3-year period with the three known PVY isolates and with isolates derived from tomato and tobacco (Table 5).

As with NewLeaf Plus plants, the coat protein m-RNA but not the protein has been detected in the NewLeaf Y plants. Since no detectable protein is produced, "seed" certification records were again examined as another means to view the stability of the inserted gene in NewLeaf Y plants. Out of 265 field lots of potatoes that were sampled, 2\% showed mosaic symptoms (Table 6). When these potatoes were serologically examined, they were found to be infected with potato virus A and not PVY. Consequently, over a 3-year period, no PVY infected potatoes were found in seed certification trials as compared with a $12 \%$ infection for non-NewLeaf Y potatoes (Table 6). PLRV was found in both NewLeaf Y and non-NewLeaf Y potatoes since neither had protection from PLRV.

\section{CONCLUSION}

After more than 10 years of research, Monsanto scientists have developed improved seed potatoes that are protected from serious pests, including insects and disease. The first commercial products resulting from this effort were NewLeaf ${ }^{\circ}$ potatoes derived from both 'Russet Burbank' and 'Atlantic' parents. The NewLeaf product was commercialized in 1995 and contains the cry3A gene from Bacillus thuringiensis (variety tenebrionis) (B.t.t.). for the production of the $\mathrm{Bt}$ protein. Potatoes expressing this gene are completely protected from the Colorado potato beetle (CPB) and need no applied chemical protection for this insect pest. The U.S. Food and Drug Administration, U.S. Dept. of Agriculture, and U.S. Environmental Protection Agency have all determined that these potatoes are the same in safety and nutritional composition as any other 'Russet Burbank' and 'Atlantic' potatoes. These potatoes have also been approved by Health Canada, Agri-Food Canada, and Agriculture Canada and by Japan and Mexico for food use.

Trait stability, as reflected in year-to-year consistency in gene expression level and protein efficacy, is critical to the successful commercial application of genetically modified crops. Commercial growers across North America have experienced outstanding performance while growing NewLeaf potatoes 5 years in a row. This level of performance is the result of stable, nonsignificant differences in expression of the cry $3 A$ gene. The stable performance, also, is a result of an effective insect resistance management program based on
Table 4. Analysis of potato leaf roll virus (PLRV) symptom development in "seed" certification samples of transgenic and nontransgenic 'Russet Burbank' potato.

\begin{tabular}{lccc}
\hline $\begin{array}{l}\text { Cultivar and } \\
\text { production } \\
\text { year }\end{array}$ & $\begin{array}{c}\text { Field } \\
\text { samples } \\
\text { (no.) }\end{array}$ & $\begin{array}{c}\text { Samples } \\
\text { with PLRV } \\
\text { (no.) }\end{array}$ & $\begin{array}{c}\text { Samples } \\
\text { with mosaic } \\
\text { (no.) }\end{array}$ \\
\hline $\begin{array}{l}\text { Newleaf®Plus Russet Burbank } \\
\quad\end{array}$ & 58 & 0 & 2 \\
$\quad 1995$ & 83 & 0 & 20 \\
1996 & 141 & 0 & 22 \\
$\quad \begin{array}{l}\text { Total } \\
\text { Unimproved Russet Burbank }\end{array}$ & 51 & 18 & 28 \\
$\quad 1995$ & 52 & 18 & 18 \\
1996 & 103 & 36 & 46 \\
Total & & & \\
\hline
\end{tabular}

Table 5. Infection of Newleaf®Y and wild-type potato with potato virus $Y$ (PVY) via artificial inoculation.

\begin{tabular}{lccc}
\hline Potato line & $\begin{array}{c}\text { Plants tested from } \\
\text { 1994-97 (no.) }\end{array}$ & $\begin{array}{c}\text { Symptoms } \\
\text { observed }^{\mathrm{z}}\end{array}$ & Optical density $^{\mathrm{y}}$ \\
\hline NewLeaf®Y RB & 15 & None & 0.153 \\
RB Control 11 & 30 & M,P,VC & 1.869 \\
RB Control 12 & 55 & M,P,VC & 0.932 \\
RB Control 13 & 25 & M,P & 0.923 \\
NewLeaf®Y SE2 & 20 & None & 0.134 \\
NewLeaf®Y SE15 & 20 & None & 0.126 \\
SE Control 1 & 65 & M & 2.217 \\
SE Control 5 & 55 & M & 1.963 \\
\hline
\end{tabular}

${ }^{\mathrm{z}}$ Symptom: $\mathrm{M}=$ mosaic; $\mathrm{P}=$ leaf puckering; $\mathrm{VC}=$ vein clearing.

${ }^{\mathrm{y}}$ Mean ELISA optical density values per potato line at their first sample period.

Table 6. Analysis of potato leaf roll virus (PLRV) and mosaic virus symptom development in "seed" certification samples of transgenic, potato virus Y (PVY) resistant and nontransgenic potato cultivars.

\begin{tabular}{|c|c|c|c|}
\hline $\begin{array}{l}\text { Cultivar and } \\
\text { production } \\
\text { year }\end{array}$ & $\begin{array}{c}\text { Field } \\
\text { samples } \\
\text { (no.) }\end{array}$ & $\begin{array}{c}\text { Samples } \\
\text { with PLRV } \\
(\%)\end{array}$ & $\begin{array}{c}\text { Samples } \\
\text { with mosaic } \\
(\%)\end{array}$ \\
\hline \multicolumn{4}{|c|}{ NewLeaf®Y Shepody and } \\
\hline \multicolumn{4}{|c|}{ Russet Burbank } \\
\hline 1995 & 20 & 5.0 & 0 \\
\hline 1996 & 88 & 6.8 & 2.3 \\
\hline 1997 & 157 & 0 & 1.9 \\
\hline Total & 265 & 2.6 & 1.9 \\
\hline \multicolumn{4}{|c|}{ Unimproved Shepody and } \\
\hline \multicolumn{4}{|c|}{ Russet Burbank } \\
\hline 1995 & 23 & 17.4 & 21.7 \\
\hline 1996 & 83 & 13.3 & 15.7 \\
\hline 1997 & 22 & 0 & 72.7 \\
\hline Total & 128 & 11.7 & 26.6 \\
\hline
\end{tabular}

${ }^{2}$ Mosaic virus symptoms can be caused by several different viruses. All mosiac symptoms in this study were due to potato virus A as determined by ELISA.

maintaining CPB refuges near NewLeaf fields, reducing CPB populations, and monitoring for CPB surviving exposure to NewLeaf potatoes.

A similar degree of trait stability, but only over a 7 year study period, has been recorded for PVY resistance and PLRV resistance. This transgenic trait stability has been noted in 12 different transgenic potato products represented by 6 different potato cultivars. Thus, NewLeaf, NewLeaf Y, and NewLeaf Plus demonstrate the genetic stability required of viable commercial products. In 1998 NewLeaf $\mathrm{Y} ®$, conferring resistance to both $\mathrm{CPB}$ and potato virus $\mathrm{Y}$, and NewLeaf Plus ${ }^{\circledR}$, conferring resistance to $\mathrm{CPB}$ and potato leaf roll virus are commercially released.

\section{Literature Cited}

Banttari,E.E.,P.J. Ellis, and S.M.P. Khurana. 1993. Management of diseases caused by viruses and viruslike pathogens, p. 103-115. In: R.C. Rowe (ed.). Potato health management. APS Press, Amer. Phytopathol. Soc., St. Paul, Minn.

Evans, M.R. (ed.) 1997. Potato facts. Econ. Res. Serv., U.S. Dept. Agr., Washington, D.C.

Ferro, D.N. and G. Boiteau. 1993. Management of insect pests, p. 103-115. In: R.C. Rowe (ed.). Potato health management. APS Press, Amer. Phytopathol. Soc., St. Paul, Minn. James, C. 1998. Global review of commercialized transgenic crops: 1998. ISAAA Briefs No. 8. Intl. Serv. for the Acquisition of Agri-biotech Applications (ISAAA). Ithaca, N.Y.

Perlak, F.J., T.B. Stone, Y.M. Muscopf, L.J. Petersen, G.B. Parker, S.A. McPherson, J.Wyman, S. Love, G. Reed, and D. Biever. 1993. Genetically improved potatoes: Protection from damage by Colorado potato beetles. Plant Mol. Biol. 22:313-321.

Slack, S.A. 1993. Seed certification and seed improvement programs, p. 103-115. In: R.C Rowe (ed.). Potato health management. APS Press, Amer. Phytopathol. Soc., St.Paul, Minn. 